\title{
Incidence Rate of Clinical Mastitis on Canadian Dairy Farms
}

\author{
R. G. M. Olde Riekerink, ${ }^{\star 1,2}$ H. W. Barkema,† D. F. Kelton,‡ and D. T. Scholl§ \\ ${ }^{*}$ Department of Health Management, University of Prince Edward Island, Charlottetown, Prince Edward Island, C1A 4P3 Canada \\ †Department of Production Animal Health, Faculty of Veterinary Medicine, University of Calgary, Calgary, Alberta, T2N 1N4 Canada \\ ‡Department of Population Medicine, University of Guelph, Guelph, Ontario, N1G 2W1 Canada \\ §Faculté de medicine vétérinaire, Université de Montréal, Saint-Hyacinthe, J25 7C6 Canada
}

\section{ABSTRACT}

No nationwide studies of the incidence rate of clinical mastitis (IRCM) have been conducted in Canada. Because the IRCM and distribution of mastitis-causing bacteria may show substantial geographic variation, the primary objective of this study was to determine regional pathogen-specific IRCM on Canadian dairy farms. Additionally, the association of pathogen-specific IRCM with bulk milk somatic cell count (BMSCC) and barn type were determined. In total, 106 dairy farms in 10 provinces of Canada participated in the study for a period of $1 \mathrm{yr}$. Participating producers recorded 3,149 cases of clinical mastitis. The most frequently isolated mastitis pathogens were Staphylococcus aureus, Escherichia coli, Streptococcus uberis, and coagulase-negative staphylococci. Overall mean and median IRCM were 23.0 and 16.7 cases per 100 cowyears in the selected herds, respectively, with a range from 0.7 to 97.4 per herd. No association between BMSCC and overall IRCM was found, but $E$. coli and culture-negative IRCM were highest and Staph. aureus IRCM was lowest in low and medium BMSCC herds. Staphylococcus aureus, Strep. uberis, and Streptococcus dysgalactiae IRCM were lowest in the Western provinces. Staphylococcus aureus and Strep. dysgalactiae IRCM were highest in Québec. Cows in tie-stalls had higher incidences of Staph. aureus, Strep. uberis, coagulase-negative staphylococci, and other streptococcal IRCM compared with those in free-stalls, whereas cows in free stalls had higher Klebsiella spp. and E. coli IRCM than those in tie-stall barns. The focus of mastitis prevention and control programs should differ between regions and should be tailored to farms based on housing type and BMSCC.

Key words: incidence rate, clinical mastitis, pathogenspecific mastitis, Canada

\footnotetext{
Received October 7, 2007.

Accepted December 19, 2007.

${ }^{1}$ Corresponding author: r.olderiekerink@gddeventer.com

${ }^{2}$ Current address: GD-Animal Health Service, Deventer, 7400AA Deventer, the Netherlands.
}

\section{INTRODUCTION}

Despite the fact that much research and effort has been dedicated to mastitis control, it remains a persistent problem and is the most expensive disease of dairy cows (Schepers and Dijkhuizen, 1991). The disease restricts farm net profit both directly and indirectly. Discarded milk and lowered production account for approximately $80 \%$ of the costs associated with mastitis (Reneau and Packard, 1991).

Several studies have been conducted in the past to estimate the incidence rate of clinical mastitis (IRCM) in Europe (Barkema et al., 1998b; Peeler et al., 2000; Barnouin et al., 2005; Nyman et al., 2006; Bradley et al., 2007), North America (Dohoo et al., 1983; Erskine et al., 1988; Bartlett et al., 1992; Sargeant et al., 1998), Australia (Daniel et al., 1982), New Zealand (McDougall, 1999), and Africa (Kivaria et al., 2006). The distribution of pathogens isolated from clinical mastitis samples differs considerably among countries and even among studies within a country. In Norway, for example, Staphylococcus aureus is the most frequently isolated bacteria from clinical mastitis samples, followed by Strep. dysgalactiae (Reksen et al., 2006). In the Midwestern United States, coliforms were the most frequently isolated bacteria (Erskine et al., 1988). In Europe, clinical Klebsiella mastitis occurs less frequently than clinical Escherichia coli mastitis, whereas in the United States, Klebsiella and E. coli mastitis are of equal importance (e.g., Barkema et al., 1998b; Roberson et al., 2004). In New Zealand, coliforms are less important as mastitis-causing pathogens; Strep. uberis is the main concern in both clinical and subclinical mastitis (McDougall, 1998).

Canadian studies of the IRCM are scarce and are limited historically and geographically. A study conducted from 1993 to 1996 in 32 herds in British Columbia found very low lactational IRCM based on farm records, ranging from 5.6 to $10.5 \%$ in cows in first lactation and in fifth and greater lactations, respectively (Van Dorp et al., 1999). More recent studies in 48 and 65 selected commercial Ontario dairies estimated the lactational IRCM to be 22 and $20 \%$, respectively 
(Sargeant et al., 1998; McLaren et al., 2006). The lactational IRCM was reported to be $17 \%$ in an earlier study in Ontario as part of a disease cohort study (Dohoo et al., 1983). No bacteriology of milk samples was performed in most Canadian studies, except in the study by Sargeant et al. (1998), who isolated Staphylococcus spp. other than Staph. aureus most often from clinical mastitis samples, followed by coliforms and Streptococcus spp.

Geometric mean BMSCC may differ by geographic region (Norman et al., 2000). An association exists between the prevalence of pathogen-specific IMI in the herd and BMSCC (Roberson et al., 2004). In addition, some studies have reported a difference in pathogenspecific IRCM related to BMSCC (Schukken et al., 1989b; Barkema et al., 1998b). Pathogen-specific IRCM may therefore differ between geographic regions.

Because no nationwide studies of the IRCM have been conducted in Canada, and because the IRCM and distribution of mastitis-causing bacteria may differ geographically, the objective of this study was to determine regional pathogen-specific IRCM on Canadian dairy farms. Additionally, the association of pathogen-specific IRCM with BMSCC and barn type was determined.

\section{MATERIALS AND METHODS}

\section{Herd Selection}

In total, 116 dairy herds in 10 provinces of Canada were purposively selected through either local veterinary practitioners or provincial Canadian Quality Milk Program (http://www.dairyinfo.gc.ca) coordinators. Of the 116 herds, 10 herds were excluded because of insufficient data. Each practitioner or coordinator selected herds based on preparedness of the producer to participate and the proximity of herds to the study center and each other. Herds participated in the study for a 12mo period between November 2003 and July 2005.

\section{Sampling}

Participating producers were asked to collect a milk sample aseptically from every quarter that had visible signs of clinical mastitis and to record cow identification; quarter; date; clinical signs such as abnormal milk, abnormal udder (swollen, red, or hard), or fever; whether the cow was off feed; teat injury; and the treatment, if the cow was treated. Every producer received a milk sampling package consisting of sample tubes, alcohol pads, latex gloves, an instruction sheet, a protocol for aseptic collection of milk samples, recording forms, and labels. Milk samples were stored in a freezer on the farm (at approximately $-20^{\circ} \mathrm{C}$ ) and collected every 4 to 6 wk by the veterinarian or the Canadian Qual- ity Milk Program coordinator, who sent the frozen milk samples on ice packs by overnight courier to the Atlantic Veterinary College (Charlottetown, Prince Edward Island) for bacterial culture.

A questionnaire was administered on every farm during the study period. The questionnaire was designed with closed questions and semiclosed questions only. Questions were tested on 3 farms and by 3 technicians at the Atlantic Veterinary College to test whether they were understood easily and interpreted correctly. The questionnaires were changed and improved where necessary. After a final version was decided on, the questionnaire was translated into French, but no further testing was conducted on this version. Upon receiving the questionnaire, all answers were coded and checked, entered twice with data-entry software (EpiData Entry; Lauritsen and Bruus, 2006), and both entries were compared, to check for errors. Specific cow and lactation data, such as calving dates, parity, and culling dates, and specific herd data, such as BMSCC and herd size, were obtained from the regional DHI organizations.

\section{Laboratory Analysis}

Bacteriological culture of milk samples was performed according to National Mastitis Council standards (Hogan et al., 1999). Staphylococcus aureus was identified by Gram stain, a positive catalase test, $\alpha$ and $\beta$-hemolysis on blood-esculin agar, and a positive tube coagulase test. Escherichia coli and Klebsiella spp. were identified by typical appearance on blood agar and were subsequently inoculated on MacConkey agar. In addition, a triple-sugar iron agar, a urea, a citrate, and a spot indole test were set up for identification. One modification was made when using highly selective media for identifying Streptococcus spp. as suggested by Zadoks et al. (2005). Streptococcus spp. not splitting esculin on a blood agar plate with $0.1 \%$ esculin were considered to be Strep. dysgalactiae; the remaining streptococci were plated on an Enterococcosel agar (BD Diagnostic Systems, Sparks, MD) and incubated for 24 $\mathrm{h}$ at $37^{\circ} \mathrm{C}$. Streptococci that were not splitting esculin on the Enterococcosel agar were considered to be Strep. uberis; the remaining organisms on Enterococcosel were considered to be group D Streptococcus or Enterococcus spp. Streptococcus agalactiae was identified by typical appearance on either modified Edward's medium or blood esculin agar, gram-positive staining, a negative catalase test, a positive Christie, Atkins, Munch-Petersen (CAMP) test, and a positive latex agglutination test (Remel PathoDx, Remel Europe Ltd., Dartford, Kent, UK).

Ten microliters of milk was cultured and the number of colony-forming units of each of the bacterial species 


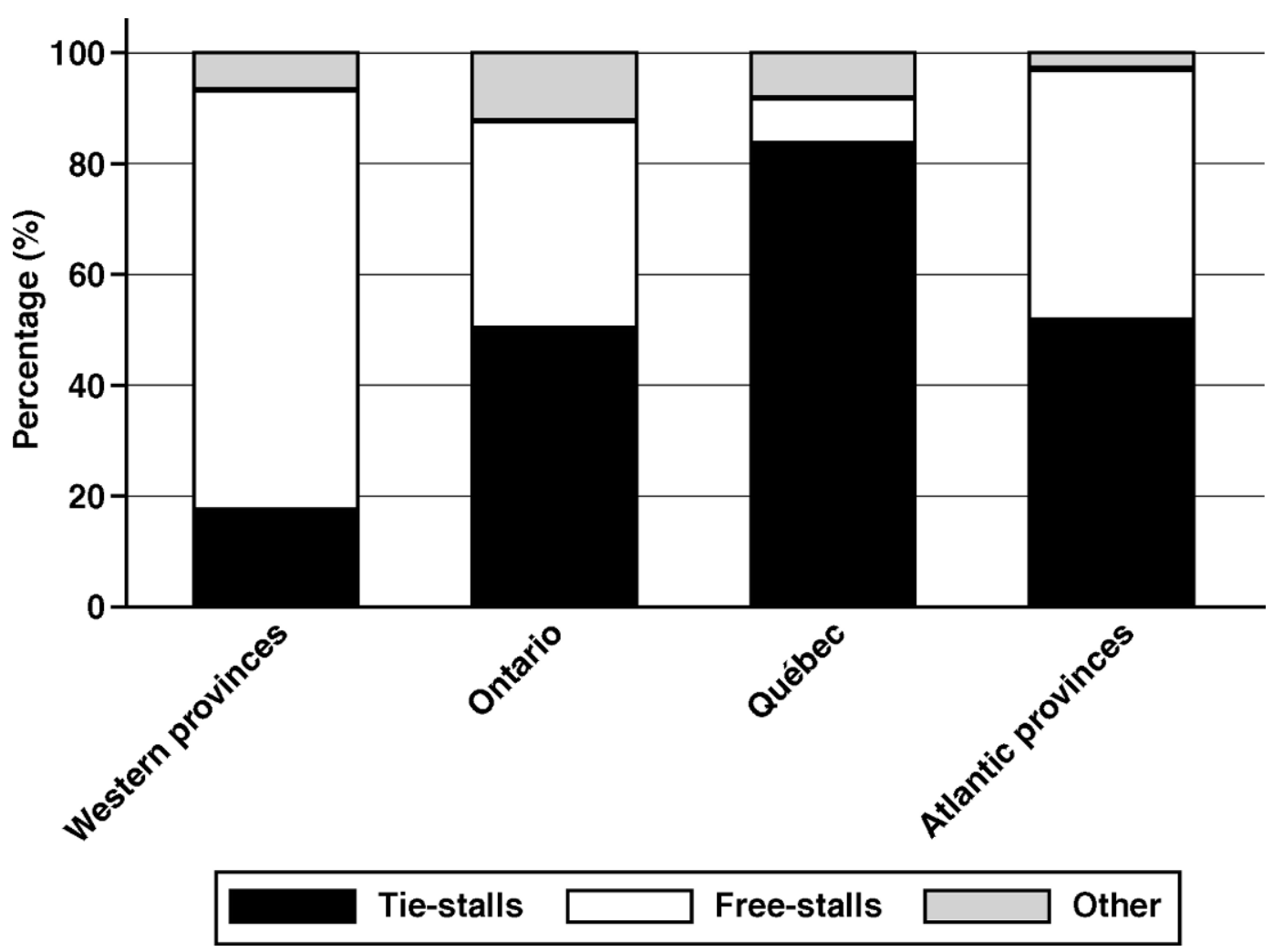

Figure 1. Distribution of lactating-cow barn types over the 4 regions of Canada of 101 (of 106) participating herds.

was counted. The contagious pathogens Staph. aureus and Strep. agalactiae were considered to cause an IMI if 1 colony ( $100 \mathrm{cfu} / \mathrm{mL}$ ) was isolated (Hogan et al., 1999). Isolation of $\geq 200 \mathrm{cfu} / \mathrm{mL}$ of environmental mastitis pathogens (E. coli, streptococci other than Strep. agalactiae, Enterococcus spp., coagulase-positive staphylococci other than Staph. aureus, Klebsiella spp., Arcanobacterium pyogenes, Serratia spp., Pseudomonas spp., and Pasteurella spp.) or $\geq 1,000 \mathrm{cfu} / \mathrm{mL}$ of Corynebacterium bovis, CNS, yeasts, molds, fungi, or Bacillus spp. was considered significant. Milk samples with 3 or more different species were considered to be contaminated unless Staph. aureus or Strep. agalactiae was isolated.

\section{Statistical Analysis}

Data were examined for unlikely values; no data were excluded for this reason. All cases of mastitis recorded by the producers were initially used in the analysis. A second or third case of clinical mastitis in the same lactation, regardless of the culture result, was considered a new case if at least $14 \mathrm{~d}$ had passed between the previous and the current case of clinical mastitis (e.g., Barkema et al., 1998b).
The association of BMSCC with IRCM was assessed by using a negative binomial regression analysis of IRCM separately on the natural logarithm of BMSCC and BMSCC category. The association of IRCM with either region, province, or barn type corrected for region was also analyzed by negative binomial regression. Regions were defined as western provinces, Ontario, Québec, and Atlantic provinces to have sufficient herd numbers per geographic region. The western provinces consisted of British Columbia, Alberta, Saskatchewan, and Manitoba. The Atlantic provinces consisted of New Brunswick, Nova Scotia, Prince Edward Island, and Newfoundland. On the basis of the geometric mean of monthly BMSCC during the study period, herds were assigned to either a low, medium, or high BMSCC category: $<150,000,150,000$ to 250,000 , or $>250,000$ cells/ $\mathrm{mL}$, respectively.

Cows were at risk during the time the herd was enrolled in the study. Per lactation, the time at risk, in days, started at the calving date, when the cow entered the herd, when the herd entered the study, or $14 \mathrm{~d}$ after the last mastitis diagnosis date. The time at risk ended when the cow had mastitis, the cow died or was culled, the farm stopped participating in the study, or the cow started a new lactation. The incidence rate was calcu- 
Table 1. Distribution of participating herds and incidence rate of clinical mastitis (IRCM) across Canadian provinces

\begin{tabular}{|c|c|c|c|c|c|c|c|c|}
\hline Province & $\begin{array}{l}\text { Number } \\
\text { of herds } \\
\text { participating } \\
\text { in study }\end{array}$ & $\begin{array}{l}\text { Number } \\
\text { of mastitis } \\
\text { cases }\end{array}$ & $\begin{array}{l}\text { Total cow } \\
\text { years } \\
\text { at risk }\end{array}$ & $\begin{array}{l}\text { Mean IRCM } \\
\text { per } 100 \\
\text { cow-years }^{1}\end{array}$ & $95 \% \mathrm{CI}^{1}$ & $\begin{array}{l}\text { Geometric } \\
\text { mean } \\
\text { BMSCC }^{2} \\
(\times 1,000 \\
\text { cells } / \mathrm{mL})\end{array}$ & $\begin{array}{c}\text { Number } \\
\text { of herds } \\
\text { as of } \\
\text { July } 31 \text {, } \\
2006^{3}\end{array}$ & $\begin{array}{c}\text { CDC } \\
\text { provincial } \\
\text { geometric } \\
\text { mean } \\
\text { BMSCC }^{3} 2005\end{array}$ \\
\hline British Columbia & 8 & 216 & 1,427 & 14.2 & $8.5-23.6$ & 149 & 641 & 180 \\
\hline Alberta & 10 & 225 & 1,210 & 20.2 & $12.8-31.9$ & 147 & 720 & 195 \\
\hline Saskatchewan & 5 & 73 & 535 & 14.2 & $7.3-27.4$ & 203 & 259 & 229 \\
\hline Manitoba & 8 & 60 & 1,395 & 7.6 & $4.3-13.3$ & 262 & 495 & 226 \\
\hline New Brunswick & 6 & 82 & 423 & 22.8 & $12.0-43.2$ & 190 & 258 & 214 \\
\hline Nova Scotia & 10 & 155 & 1,300 & 14.0 & $8.7-22.4$ & 160 & 297 & 214 \\
\hline Prince Edward Island & 16 & 230 & 1,278 & 18.6 & $12.8-27.0$ & 146 & 246 & 207 \\
\hline Newfoundland & 1 & 113 & 378 & 29.9 & $7.4-120.2$ & 243 & 41 & $-^{4}$ \\
\hline Total & 106 & 2,152 & 11,477 & $23.0^{5}$ & & 184 & 15,522 & - \\
\hline
\end{tabular}

${ }^{1} \mathrm{CI}=$ mean and confidence interval (CI) derived from a negative binomial model with IRCM as outcome and province as independent variable.

${ }^{2}$ BMSCC $=$ bulk milk SCC.

${ }^{3}$ Source: Canadian Dairy Commission (CDC; http://www.dairyinfo.gc.ca/_english/dff/dff_2/dff_2c_e.htm; last accessed Oct. 7, 2007).

${ }^{4}$ Data not available.

${ }^{5}$ Crude mean IRCM of all herds.

lated as the number of mastitis cases per $36,500 \mathrm{~d}$ at risk (100 cow-years) in a herd. Incidence rate, time at risk, and overdispersion of the models were assessed as described by Dohoo et al. (2003). All statistical analyses were performed by using Intercooled Stata 8.2 (Intercooled Stata for Windows, version 8.2, Stata Corporation, College Station, TX).

\section{RESULTS}

Lactating cows were housed in 3 different barn types: 50 free-stalls (49.5\%), 44 tie-stalls (43.6\%), and 7 straw packs or a combination of barn types (6.9\%; barn type was not established in 5 herds). Free-stall barns were the most common in the western provinces, whereas tie-stall barns were the most common in Québec (Figure 1). The Atlantic provinces and Ontario had approximately equal proportions of tie-stalls and free-stalls (Figure 1). The average herd size was 106 cows and ranged between 23 and 649 cows (dry and lactating cows). Because a proportional representation of farms across the Canadian provinces was attempted, Québec had the largest proportion of participating herds (26; $24.5 \%)$ whereas only 1 Newfoundland herd $(0.9 \%)$ participated (Table 1). The geometric mean BMSCC was the lowest on the participating Prince Edward Island farms (146,000 cells/mL; Table 1$)$, whereas the participating Manitoba farms had the highest geometric mean BMSCC $(262,000$ cells $/ \mathrm{mL})$.

Producers that submitted milk samples recorded 3,149 cases of clinical mastitis and submitted 3,033 samples ( $96.3 \%$ of cases had samples submitted). Masti- tis pathogens that were isolated most often were Staph. aureus, E. coli, Strep. uberis, and CNS (Table 2). No bacteria were isolated in 1,330 (43.9\%) samples, and $262(8.6 \%)$ samples were considered contaminated. Streptococcus agalactiae was found in $4(0.1 \%)$ clinical mastitis cases, all of which were retrieved from 1 farm in Québec. Severity was recorded in 2,311 (73\%) of the recorded clinical mastitis cases. In $230(10 \%)$ cases, the cow was off feed or had a fever.

The mean herd IRCM was 23.0 cases per 100 cowyears in the selected herds and the median IRCM was 16.7 cases per 100 cow-years, ranging from 0.7 to 97.4 per herd (Figures 2 and 3, and Table 1). Incidence rates were different by province $(P<0.01$; Table 1$)$. Ontario had the highest IRCM, 31.2 cases per 100 cow-years, compared with Manitoba, where the IRCM was 7.6 cases per 100 cow-years. Herds in Ontario and Québec had the highest mean herd IRCM compared with other regions, and the herds in the Western provinces had the lowest IRCM (Table 1). The IRCM was highest in the first week after calving, declined considerably in the second week, and showed a declining trend toward late lactation and a slight upward trend from wk 45 onward (Figure 4). Heifers had a higher IRCM than older cows in the first $2 \mathrm{wk}$ of lactation, between $2 \mathrm{wk}$ and $45 \mathrm{wk}$ they had a lower IRCM than older cows, and late to very late in lactation heifers and older cows tended to have similar IRCM (Figure 4).

No association was found between overall IRCM and BMSCC ( $P=0.70$; Figure 5 ). The low, medium, and high BMSCC categories consisted of 30 (28\%), 52 (49\%), and $24(23 \%)$ herds, respectively, after categorization. 
Table 2. Distribution of mastitis pathogens in 3,033 submitted milk samples from 106 dairy farms in 10 Canadian provinces

\begin{tabular}{lccc}
\hline Pathogen & Frequency & $\begin{array}{c}\text { Percentage } \\
\text { of samples }(\%)\end{array}$ & $\begin{array}{c}\text { Percentage } \\
\text { of isolates }(\%)\end{array}$ \\
\hline Staphylococcus aureus & 312 & 10.3 & 21.7 \\
Escherichia coli & 254 & 8.4 & 17.6 \\
Streptococcus uberis & 191 & 6.3 & 13.3 \\
CNS & 154 & 5.1 & 10.7 \\
Klebsiella spp. & 131 & 4.3 & 9.1 \\
Streptococcus dysgalactiae & 121 & 4.0 & 8.4 \\
Enterococcus spp. & 68 & 2.2 & 4.7 \\
Streptococcus spp. & 63 & 2.1 & 4.4 \\
Yeast & 57 & 1.9 & 4.0 \\
Arcanobacterium pyogenes & 37 & 1.2 & 2.6 \\
Bacillus spp. & 32 & 1.1 & 2.2 \\
Pseudomonas spp. & 23 & 0.8 & 1.6 \\
Serratia & 11 & 0.4 & 0.8 \\
Corynebacterium bovis & 6 & 0.2 & 0.4 \\
Staphyloccus spp. & 4 & 0.1 & 0.3 \\
Streptoccus agalactiae & 4 & 0.1 & 0.3 \\
Pasteurella spp. & 1 & 0.0 & 0.1 \\
Other & 51 & 1.7 & 3.5 \\
Mixed culture & 82 & 2.7 & - \\
Culture-negative & 1330 & 83.9 & - \\
Contamination & 262 & 8.6 & - \\
Not sampled but recorded & 116 & - & - \\
\hline
\end{tabular}

Low and medium BMSCC herds had higher IRCM than did high BMSCC herds (Table 3). Staphylococcus aureus IRCM was higher in the high BMSCC herds than in the medium BMSCC herds, but not significantly, whereas the Staph. aureus IRCM in low BMSCC herds was significantly higher than that in medium BMSCC herds (Table 3). The E. coli IRCM was higher in low and medium BMSCC herds than in high BMSCC herds. The culture-negative IRCM was higher in low and medium BMSCC herds than in high BMSCC herds (Table 3).

Across Canada, pathogen-specific IRCM differed by region. The Staph. aureus, Strep. uberis, and Strep. dysgalactiae IRCM were lowest in the Western provinces (Table 4). Contagious pathogens (Staph. aureus and Strep. dysgalactiae) had the highest IRCM in Québec. Cows in tie-stalls had a higher Staph. aureus, Strep. uberis, CNS, and other streptococcal IRCM compared with those in free-stalls, whereas cows in free stalls had higher Klebsiella spp. IRCM than those in tie-stall barns (Table 5).

\section{DISCUSSION}

The estimated IRCM of 23.0 clinical mastitis cases per 100 cow-years corresponded to the range of IRCM reported by others (Wilesmith et al., 1986; Erskine et al., 1988; Schukken et al., 1989b; Barkema et al., 1998b). The reported IRCM also fell into the range of IRCM found by other authors in Canada. The estimates of Sargeant et al. (1998) and McLaren et al. (2006) were similar, those of Van Dorp et al. (1999) were much lower [642 (7.3\%) cases in 8,828 lactations], and those of Meek et al. (1986) were higher (0.37 cases per animal-year). Considerable ranges of IRCM were found in different studies, varying from 9\% per 3-mo early-lactation period in Australia (Daniel et al., 1982) to 54.6 cases per 100 cow-years in British dairy herds (Wilesmith et al., 1986). Differences in selection criteria, country, environmental conditions, housing, sampling season,

Table 3. Incidence rate of clinical mastitis (IRCM per 100 cow-years) for selected pathogens within 3 bulk milk SCC (BMSCC; $\times 1,000$ cells $/ \mathrm{mL}$ ) categories on 101 Canadian dairy farms, corrected for barn type and region

\begin{tabular}{lccc}
\hline & \multicolumn{3}{c}{ BMSCC } \\
\cline { 2 - 4 } & $\begin{array}{c}<150 \\
(\mathrm{n}=29)\end{array}$ & $\begin{array}{c}151 \text { to } 250 \\
(\mathrm{n}=51)\end{array}$ & $\begin{array}{c}>250 \\
(\mathrm{n}=21)\end{array}$ \\
\hline Pathogen & $2.78^{\mathrm{a}}$ & $2.26^{\mathrm{a}, \mathrm{c}}$ & $3.97^{\mathrm{c}}$ \\
Staphylococcus aureus & $1.97^{\mathrm{a}}$ & $1.92^{\mathrm{b}}$ & $0.71^{\mathrm{ab}}$ \\
Streptococcus uberis & $1.83^{\mathrm{a}}$ & $1.06^{\mathrm{a}}$ & 2.02 \\
CNS & 1.11 & 1.18 & 0.99 \\
Streptococcus dysgalactiae & 0.63 & 0.97 & 1.08 \\
Streptococcus spp. & $1.03^{\mathrm{a}}$ & $0.81^{\mathrm{c}}$ & $0.36^{\mathrm{a}, \mathrm{c}}$ \\
Klebsiella spp. & 0.47 & 0.83 & 0.40 \\
Culture-negative & $6.09^{\mathrm{a}}$ & $6.43^{\mathrm{b}}$ & $2.23^{\mathrm{ab}}$ \\
Overall IRCM & $22.6^{\mathrm{a}}$ & $24.9^{\mathrm{b}}$ & $16.2^{\mathrm{ab}}$ \\
\hline
\end{tabular}

${ }^{\mathrm{a}, \mathrm{b}}$ IRCM on the same row having a common superscript differ $(P$ $\leq 0.05)$.

'IRCM on the same row having a common superscript differ $(0.05$ $<P \leq 0.10)$. 
Table 4. Incidence rate of clinical mastitis (IRCM per 100 cow-years) for selected pathogens within region on 101 Canadian dairy farms

\begin{tabular}{lccccc}
\hline & \multicolumn{5}{c}{ Region } \\
\cline { 2 - 5 } Pathogen & $\begin{array}{c}\text { Western provinces } \\
(\mathrm{n}=29)\end{array}$ & $\begin{array}{c}\text { Ontario } \\
(\mathrm{n}=16)\end{array}$ & $\begin{array}{c}\text { Québec } \\
(\mathrm{n}=25)\end{array}$ & $\begin{array}{c}\text { Atlantic provinces } \\
(\mathrm{n}=33)\end{array}$ & All herds \\
\hline Staphylococcus aureus & $1.80^{\mathrm{a}}$ & 3.11 & $3.98^{\mathrm{ab}}$ & $2.70^{\mathrm{b}}$ & 2.88 \\
Escherichia coli & $1.37^{\mathrm{a}}$ & $3.02^{\mathrm{ab}}$ & 1.53 & $1.36^{\mathrm{b}}$ & 1.71 \\
Streptococcus uberis & $0.76^{\mathrm{abc}}$ & $2.06^{\mathrm{a}}$ & $1.60^{\mathrm{b}}$ & $2.00^{\mathrm{c}}$ & 1.55 \\
CNS & $0.90^{\mathrm{e}}$ & $1.59^{\mathrm{f}}$ & $1.69^{\mathrm{e}}$ & $0.70^{\mathrm{f}}$ & 1.15 \\
Streptococcus dysgalactiae & $0.27^{\mathrm{abc}}$ & $1.43^{\mathrm{ae}}$ & $1.69^{\mathrm{bde}}$ & $0.66^{\mathrm{cd}}$ & 0.93 \\
Klebsiella spp. & $1.01^{\mathrm{a}}$ & 0.85 & $0.27^{\mathrm{a}}$ & 0.53 & 0.65 \\
Streptococcus spp. & $0.39^{\mathrm{ae}}$ & 0.66 & $1.20^{\mathrm{a}}$ & $0.92^{\mathrm{e}}$ & 0.79 \\
Culture-negative & 4.25 & $8.26^{\mathrm{e}}$ & 6.62 & $4.44^{\mathrm{e}}$ & 5.54 \\
Overall IRCM & $15.6^{\mathrm{ab}}$ & $32.5^{\mathrm{ac}}$ & $30.4^{\mathrm{bd}}$ & $18.7^{\mathrm{cd}}$ & 23.0 \\
\hline
\end{tabular}

${ }^{\mathrm{a}-\mathrm{d}}$ IRCM on the same row having a common superscript differ $(P \leq 0.05)$.

e,fIRCM on the same row having a common superscript differ $(0.05<P \leq 0.10)$.

method of data collection, and definition of clinical mastitis undoubtedly contributed to these differences. Methodological differences require caution in comparing IRCM between investigations, but assumed regional differences and barn type differences also underscore the view that mastitis- and milk quality-control programs should be tailor-made for the specific geographic region and barn type in which cows are housed.

Studies such as this one, in which producers selected and sampled cows with clinical mastitis, have some drawbacks. First, the herds were selected for convenience. This method was chosen because producers were asked to take samples and keep records of all clinical mastitis cases. It is likely that this resulted in an overrepresentation of compliant, cooperative producers or producers with mastitis problems who saw this project as an opportunity to get free culturing of milk samples. In this study, many farms had a lower BMSCC compared with the average provincial BMSCC as recorded by the Canadian Dairy Commission (Table 1). These farms represent a different type of management than high BMSCC herds (Barkema et al., 1998a). Producers that were willing to participate were also likely to be more motivated to reduce IRCM on their farms. This convenience selection could have caused an underestimation of the true IRCM in Canadian dairy herds. On the other hand, the herd selection method provided an opportunity for the participating veterinarians to include farms with mastitis problems in the project. Second, detection bias or misclassification bias might have caused underestimation of the IRCM because definitions of clinical mastitis might differ between producers. Each herd was provided with the project definition of clinical mastitis; however, because of the study design, the authors were not able to validate the producers' definition of clinical mastitis. Third, particularly for this study, there was no direct contact be- tween the researcher and the producers, or between the researchers and the veterinarians or Canadian Quality Milk coordinators, which might have curbed the motivation for both coordinators and producers to take samples and might have caused an underestimation of IRCM. In comparison, Barkema et al. (1998b) personally visited every farm every 6 to $8 \mathrm{wk}$, and this might have been a reason that the IRCM in his study was higher than in the present study. Although these reasons are major drawbacks in estimating the IRCM, alternatively, visiting every farm to diagnose every case of clinical mastitis would require an enormous financial and human workforce effort. Additionally, the researcher's estimation of IRCM might not reflect the producer's perceived IRCM. Therefore, the data collection methods used in this study were the most feasible and pragmatic approaches under the given circumstances.

Detection bias could also have occurred because of the severity of clinical mastitis, which is related to the pathogens isolated (Gröhn et al., 2005). Producers could

Table 5. Incidence rate of clinical mastitis (IRCM per 100 cow-years) for selected pathogens within 3 barn types on 101 Canadian dairy farms, corrected for region

\begin{tabular}{lccc}
\hline & \multicolumn{3}{c}{ Barn type for lactating cows } \\
\cline { 2 - 4 } & $\begin{array}{l}\text { Tie-stall } \\
(\mathrm{n}=50)\end{array}$ & $\begin{array}{c}\text { Free-stall } \\
(\mathrm{n}=44)\end{array}$ & $\begin{array}{c}\text { Other } \\
(\mathrm{n}=7)\end{array}$ \\
\hline Pathogen & $4.04^{\mathrm{a}}$ & $1.62^{\mathrm{a}}$ & 1.62 \\
Staphylococcus aureus & 1.36 & 2.08 & 1.27 \\
Escherichia coli & $2.19^{\mathrm{a}}$ & $0.67^{\mathrm{ab}}$ & $2.65^{\mathrm{b}}$ \\
Streptococcus uberis & $1.58^{\mathrm{a}}$ & $0.68^{\mathrm{a}}$ & 0.74 \\
CNS & 0.89 & 0.87 & 1.34 \\
Streptococcus dysgalactiae & $0.40^{\mathrm{a}}$ & $1.00^{\mathrm{a}}$ & 0.28 \\
Klebsiella spp. & $1.21^{\mathrm{a}}$ & $0.37^{\mathrm{a}}$ & 0.56 \\
Streptococcus spp. & 5.45 & 5.73 & 4.32 \\
Culture-negative & $26.6^{\mathrm{a}}$ & $19.1^{\mathrm{a}}$ & 19.5 \\
Overall IRCM &
\end{tabular}

${ }^{\mathrm{a}, \mathrm{b}} \mathrm{IRCM}$ on the same row having a common superscript differ $(P$ $\leq 0.05)$. 


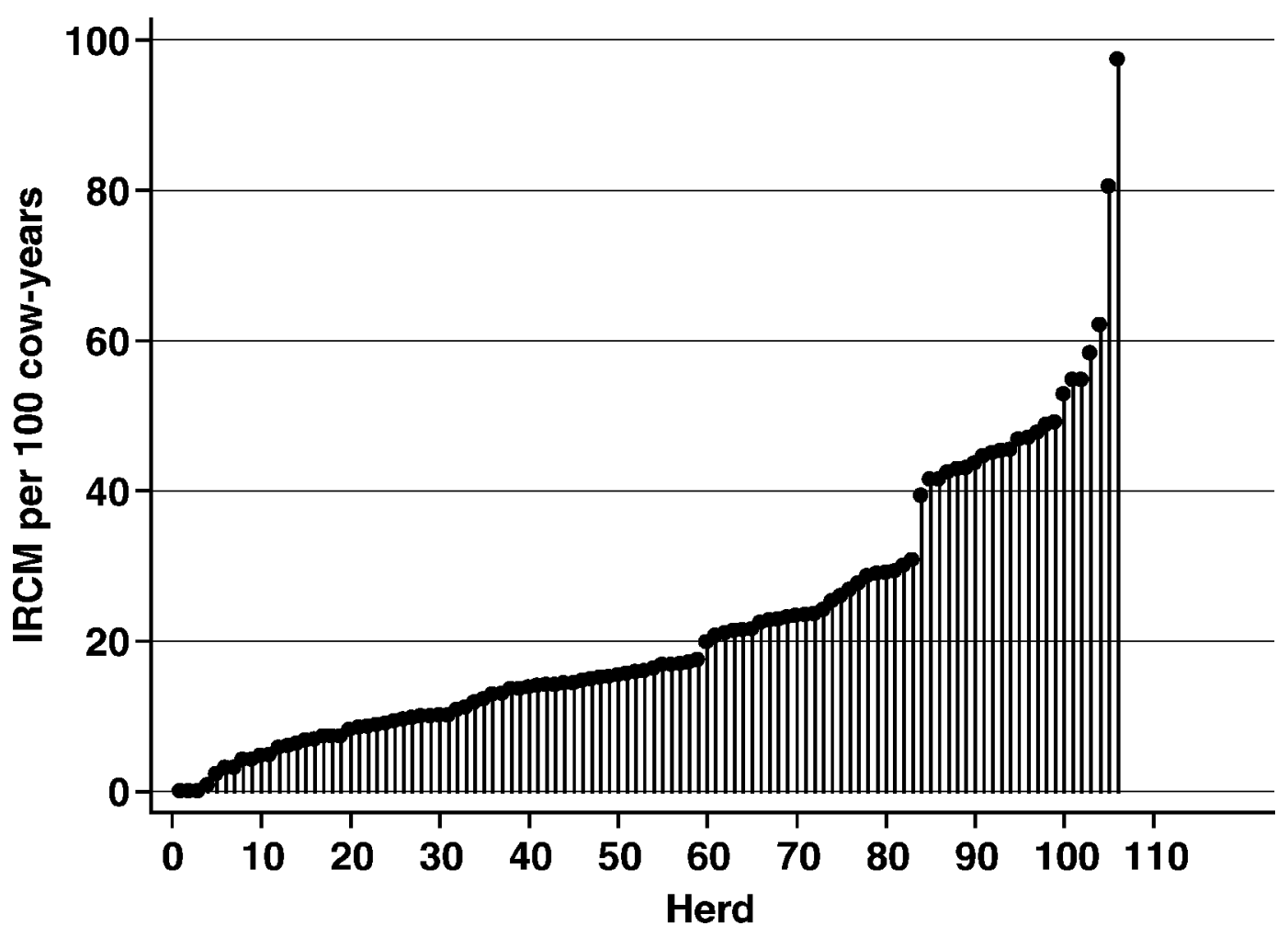

Figure 2. Incidence rate of clinical mastitis (IRCM) in 106 Canadian dairy herds that submitted milk samples.

be more likely to sample cows with severe clinical mastitis than cows with less severe symptoms. Detection bias could have differed among farms. Producers who scrutinized foremilk more carefully than other producers (Barkema et al., 1999) could have detected more clinical mastitis cases. However, Lam et al. (1993) concluded, in a study performed in the Netherlands, that the diagnostic capability of producers did not have a negative influence on the validity of producer-observed clinical mastitis incidence in low BMSCC herds.

Because veterinarians in Sweden are required to initiate every treatment involving antibiotics, a recent study reported that producers with high veterinarytreated IRCM were more motivated to treat clinical mastitis than producers that had low IRCM (Nyman et al., 2006). Another method, used in a study in British Columbia, Canada, relied on farm records only (Van Dorp et al., 1999) and possibly resulted in a relatively low IRCM, because producers might not record every case of mastitis. They might have chosen to record only cases of mastitis that were treated, contrary to our study, in which producers were instructed to take milk samples of every case of clinical mastitis, regardless of treatment. Just under half of the cases of clinical mastitis were not treated in our study (results not shown); we hypothesize that these cases were mild cases of clinical mastitis and that producers normally record fewer of these cases. This is possibly reflected in the higher IRCM we found in our study compared with the report of Van Dorp et al. (1999), because we emphasized to the producers to take milk samples of every case of clinical mastitis.

The IRCM reported in this study was higher than the IRCM reported in the most recent study in Ontario (Sargeant et al., 1998). Sargeant et al. (1998) calculated the IRCM by using exclusively full 305-d lactations. However, an underestimation of true IRCM could occur here because cows with clinical mastitis are more likely to be culled before the end of lactation (Seegers et al., 2003).

Herds in Ontario and Québec had a higher IRCM than herds in other regions. More than half of the barns in these regions were tie-stall barns. The difference in IRCM could be explained by the different management styles directly related to the barn type and different IMI risks associated with barn type. In tie-stall barns, it is easier to milk cows with clinical mastitis last or with a separate unit. In free-stall barns, wood shavings are used more often as stall bedding material than in tie-stall barns. Cows kept in tie-stall barns also had proportionally more clinical Staph. aureus and Strep. uberis mastitis compared with those in free-stall barns. 


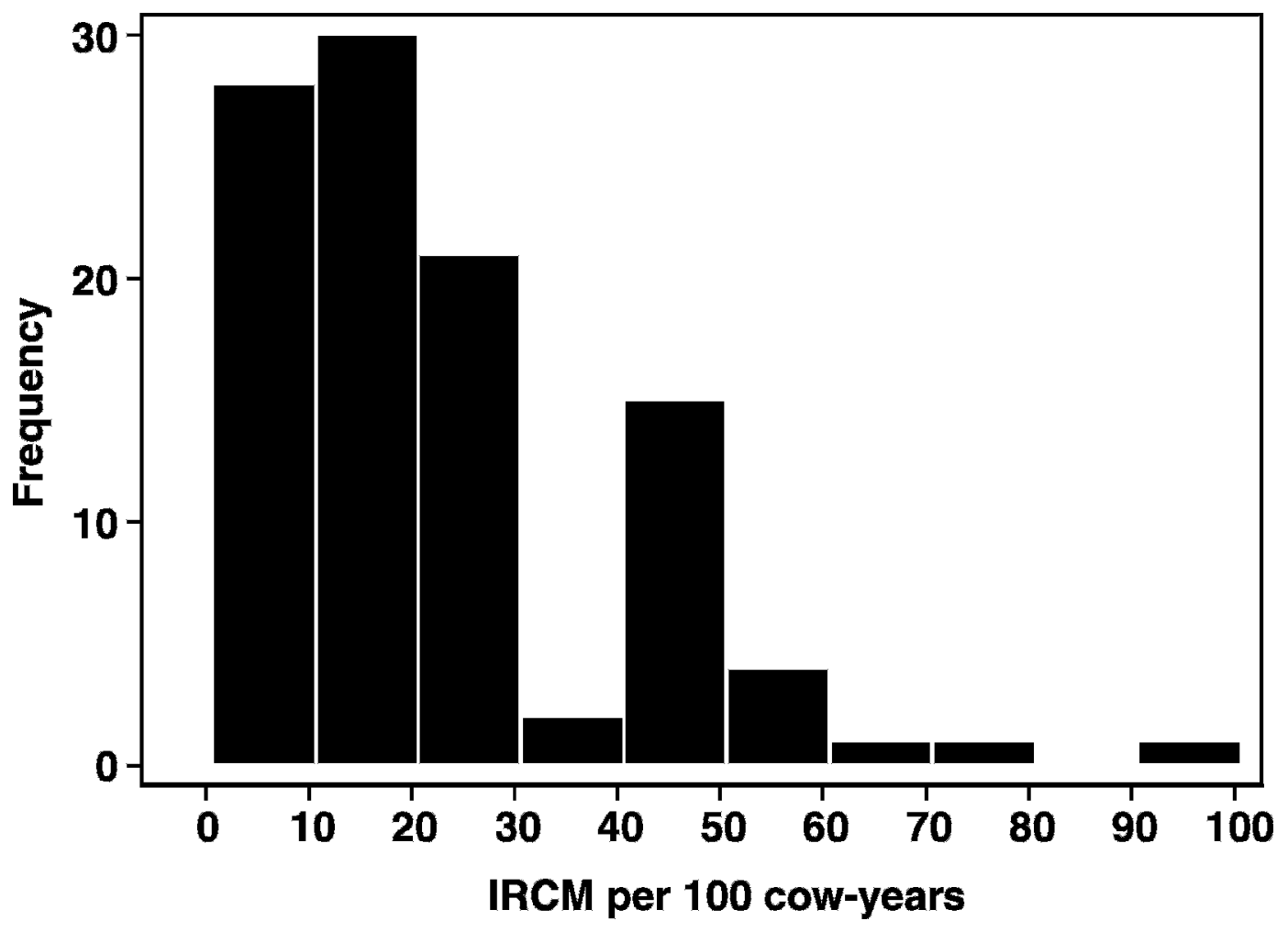

Figure 3. Distribution of incidence rate of clinical mastitis (IRCM) on 106 Canadian dairy farms.

More udders are infected with Staph. aureus in Scandinavian countries, specifically Norway and Sweden, which have more tie-stall barns (Østerås et al., 1999). Staphylococcus aureus is considered a contagious pathogen (Fox and Gay, 1993), and the spread and prevalence of this pathogen could be attributed to udder preparation procedures in tie-stall barns. Streptococcus dysgalactiae had the highest IRCM in Québec, where most herds are kept in tie-stall barns, although Strep. dysgalactiae IRCM was not significantly associated with barn type in our study.

The distribution of barn types in this study was similar to that in previous research in a random sample of herds (Olde Riekerink et al., 2006a). Tie-stall barns were more common in Ontario, Québec, and the eastern provinces (Olde Riekerink et al., 2006a) and were positively associated with higher IRCM. Western provinces, such as British Columbia and Alberta, had few or no tie-stall barns compared with other provinces. Region could therefore be a confounder for differences in IRCM between housing systems. When starting a dairy farm in a certain region, a regional common barn type is most likely installed, whereas certain regional styles of farming might have a direct effect on IRCM. The difference in Staph. aureus IRCM was therefore most likely the result of the prevailing barn types by region.
By contrast, Strep. dysgalactiae IRCM differed significantly by region and seemed not to be associated with either free-stall or tie-stall barns. An explanation for these regional differences could be sought, for example, in differences in management style, tradition, and herd size. Regional differences in IRCM could therefore be explained only partly by the regional appearance of certain barn types.

The diagnostic tests for mastitis that are described in the Laboratory Handbook on Bovine Mastitis of the National Mastitis Council (Hogan et al., 1999) to differentiate the most frequently isolated Streptococcus spp. are the CAMP, inulin, hippurate, esculin, and $\mathrm{NaCl}$ tests. A table is provided in this book showing how Strep. agalactiae, Strep. uberis, and Strep. dysgalactiae should react. The $\mathrm{NaCl}$ test is used to differentiate between streptococci and enterococci (Brown et al., 1983). However, in our experience, this test is unreliable. Of a set of 10 Enterococcus spp. based on a positive $\mathrm{NaCl}$ test, further diagnostics using PCR techniques (Zadoks et al., 2005) identified 7 isolates as Strep. uberis (results not published). The tests that are recommended by the National Mastitis Council are difficult to interpret, because test combinations do not always match and often the diagnoses are "other" Streptococcus or Enterococcus spp. The authors decided to use Enterococcosel agar to 


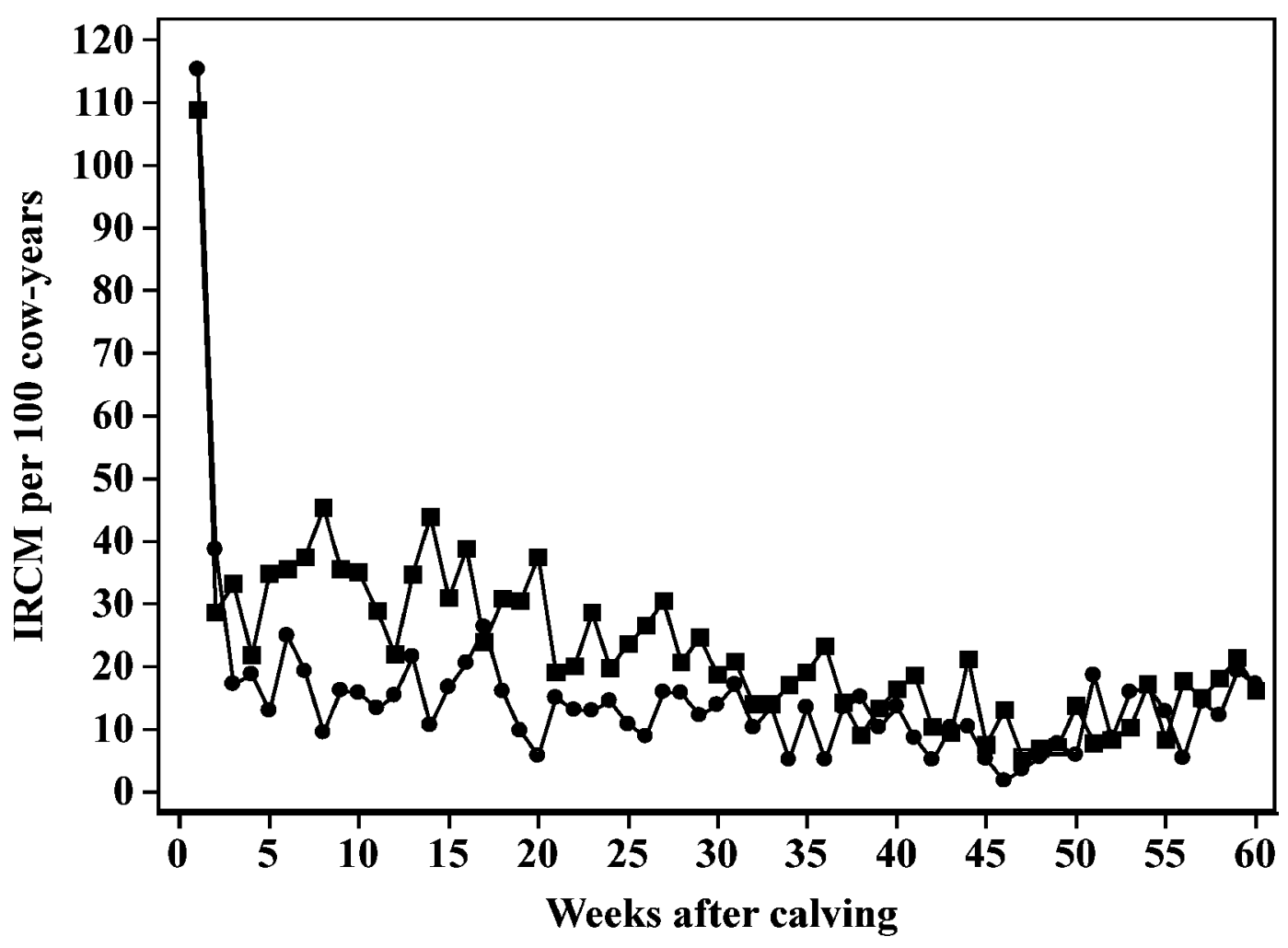

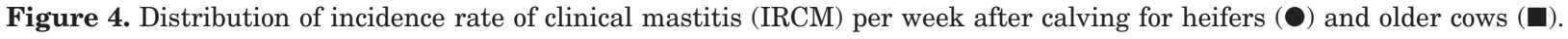

differentiate Enterococcus spp. from non-group D Streptococcus spp. in addition to the tests recommended by the National Mastitis Council. The proportions of clinical mastitis caused by Strep. uberis, Strep. dysgalactiae, and Enterococcus spp. better reflected the proportions that were to be expected, similar to other studies (Barkema et al., 1998b) using Enterococcosel agar.

Staphylococcus aureus was the most frequently isolated pathogen in clinical mastitis, followed by $E$. coli and Strep. uberis. In an earlier study on herd-level prevalences of contagious mastitis pathogens in Canadian dairy herds, Staph. aureus was isolated from bulk milk in $74 \%$ of a random selection of 291 herds (Olde Riekerink et al., 2006a). Finding Staph. aureus most often in milk samples of clinical mastitis was not surprising. Coliforms were most often isolated from cases of clinical mastitis in a study in Ontario (Sargeant et al., 1998), although further differentiation was not performed. Klebsiella spp. were the fifth most frequently isolated pathogens. Recently, researchers have suggested that the incidence of Klebsiella is higher in North America than in Europe (Roberson et al., 2004) and that it is an emerging pathogen in North America (Zadoks and Munoz, 2007). However, husbandry on Canadian dairy farms, particularly in Québec, Ontario, and Atlantic Canada, differs from that on US farms and is more similar to the Western European situation. As a result, the pathogen distribution of western Canadian dairy farms is similar to that of herds with a low BMSCC in the United States (Table 4; Erskine et al., 1988). In the other regions of Canada, the distribution is similar to what was found in European studies (Barkema et al., 1998b). Proportion of CNS was similar to that in a recent clinical mastitis incidence study in the United Kingdom (Bradley et al., 2007). It is difficult to judge whether the cultured CNS were the causative agent of the clinical mastitis or teat canal inhabitants. However, CNS can cause mild to severe clinical mastitis (Jarp, 1991), and some have reported an increase in the CNS IRCM (Taponen and Pyörälä, 2007).

Culture-negative milk samples represented a large part of the milk sample culture results. One of the reasons for a milk sample of a clinical mastitis case to be culture negative in this study is that a considerable proportion of samples were frozen for a few weeks between sampling and culture in the laboratory. Another reason could be that those mastitis cases might have been caused by Mycoplasma. Samples were not tested for Mycoplasma spp. because this requires special growth media. This seems unlikely, however, because the incidence of Mycoplasma mastitis is generally not so high that it could explain most of the culture-negative 


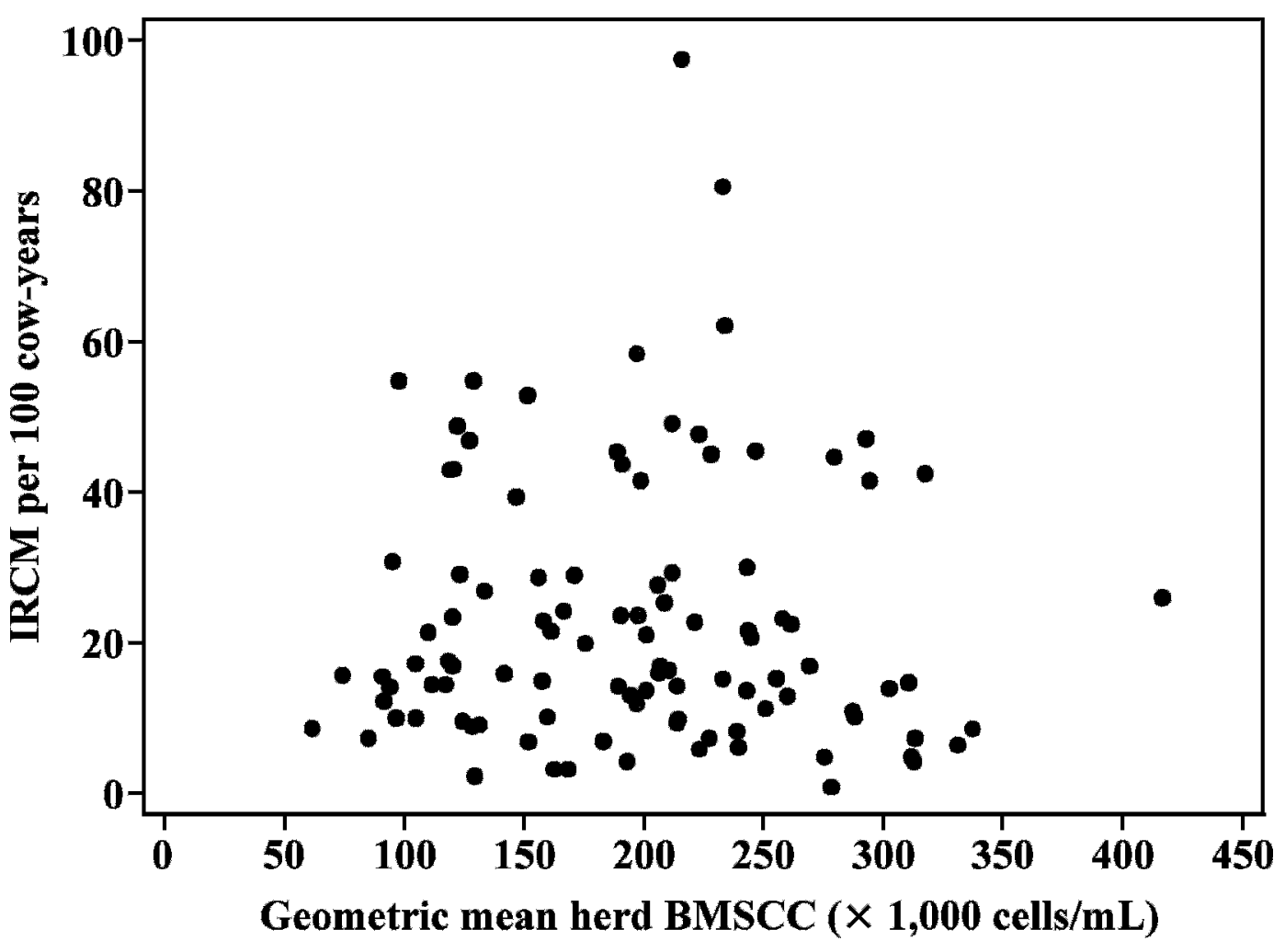

Figure 5. Incidence rate of clinical mastitis (IRCM) vs. geometric mean bulk milk SCC (BMSCC) on 106 Canadian dairy farms.

samples, and the clinical appearance of the culturenegative mastitis cases did not suggest Mycoplasma mastitis. It would be fair to state, based on a recent study in Prince Edward Island, that Mycoplasma prevalence is most likely low in Canada (Olde Riekerink et al., 2006b). Culture-negative results are often attributed to either E. coli (Smith and Hogan, 1993) or Staph. aureus (Sears et al., 1990). The distribution of culture-negative IRCM was strikingly similar to the $E$. coli IRCM across BMSCC groups (Table 3), regions (Table 4), and barn types (Table 5), whereas the Staph. aureus IRCM had different distributions. This suggests that a great proportion of the culture-negative clinical mastitis cases were caused by $E$. coli, or at least a pathogen with similar properties, and that this pathogen was not present or viable in the milk sample collected (Zorah et al., 1993) or did not survive the frozen storage before culture (Schukken et al., 1989a).

No linear relationship was found between BMSCC and overall IRCM in this study. This is consistent with some previous research (Barkema et al., 1998b), although other authors have reported an association (Erskine et al., 1988). An association between BMSCC and pathogen-specific IRCM was observed, consistent with the findings of Barkema et al. (1998b). Barkema et al. (1998b) reported that herds with low BMSCC had a higher E. coli and Strep. dysgalactiae IRCM and herds with a high BMSCC had a higher IRCM with contagious mastitis pathogens, such as Staph. aureus. Similar to Barkema et al. (1998b), there was a higher Staph. aureus IRCM in the high BMSCC herds compared with other BMSCC categories and a higher E. coli and culture-negative IRCM in the medium and low BMSCC herds compared with the high BMSCC category, indicating a pathogen-specific difference in IRCM between the BMSCC categories. These findings could suggest that mainly contagious mastitis pathogens contributed to a high BMSCC. If the number of herds in this study had been larger and if the estimates are correct, the additional statistical power might have led to more significant differences in pathogen-specific IRCM between BMSCC categories. The higher BMSCC is most likely caused by an increased Staph. aureus IRCM. Herds with a high Staph. aureus IRCM possibly have more subclinical Staph. aureus infections than herds with a low Staph. aureus IRCM. A higher prevalence of Staph. aureus in the herd is likely associated with a higher frequency of Staph. aureus isolation from consecutive bulk milk samples, which in turn is associated with a higher BMSCC (Jayarao et al., 2004; Olde Riekerink et al., 2006b). 


\section{CONCLUSIONS}

The mean IRCM in Canadian dairy herds was 23.0 cases per 100 cow-years and ranged widely between herds. The provinces Ontario and Québec had the highest IRCM, possibly associated with the predominant barn type in those regions being tie-stalls. Staphylococcus aureus and streptococcal IRCM were highest in tiestall barns, whereas $E$. coli IRCM was highest in freestall barns. The most frequently isolated pathogens in clinical mastitis were Staph. aureus, E. coli, Strep. uberis, and CNS. There was no association between BMSCC and overall IRCM in this study, although pathogen-specific IRCM differed between BMSCC categories. Mastitis prevention and control programs should therefore differ by region and should be tailored to housing type and BMSCC.

\section{ACKNOWLEDGMENTS}

The authors would like to thank all participating producers for their time and effort; the coordinators and their staff: Rich Vanderwal, Colin Radom, Chris Dunn, Phil Klassen, Cheryl Schroeder, John Ayres, Jessie Smitham, Guy Boisclair, Jodi Wallace, Daniel Gauthier, Marc Verschoor, Jessica Harvey-Chappell, Gloria Martin, Nancy Douglas, Vicki O'Leary, and Pauline Duivenvoorden; Doris Poole for all laboratory analyses; veterinary students Frieda Berg, Wytske Veenstra, Wade Sweet, Katie MacIntosh, Shelly Meleck, and Mike Trenholm; and veterinary technicians Theresa Andrews, Lloyd Dalziel, and Barb Enman, and Julie Baillargeon for translating documents. This research was funded by the National Science and Engineering Research Council of Canada (NSERC, Ottawa, ON, Canada), Dairy Farmers of Canada (DFC, Ottawa, ON, Canada), and the Atlantic Veterinary College (Charlottetown, PEI, Canada), in collaboration with the Canadian Bovine Mastitis Research Network (whose partners include Valorisation Recherche Québec, NSERC, DFC, Alberta Milk, Dairy Farmers of Ontario, Novalait Inc., Dairy Farmers of Nova Scotia, Dairy Farmers of New Brunswick, Dairy Farmers of Prince Edward Island, and the Canadian Dairy Network).

\section{REFERENCES}

Barkema, H. W., Y. H. Schukken, T. J. Lam, M. L. Beiboer, G. Benedictus, and A. Brand. 1998a. Management practices associated with low, medium, and high somatic cell counts in bulk milk. J. Dairy Sci. 81:1917-1927.

Barkema, H. W., Y. H. Schukken, T. J. Lam, M. L. Beiboer, H. Wilmink, G. Benedictus, and A. Brand. 1998b. Incidence of clinical mastitis in dairy herds grouped in three categories by bulk milk somatic cell counts. J. Dairy Sci. 81:411-419.

Barkema, H. W., J. D. Van der Ploeg, Y. H. Schukken, T. J. Lam, G. Benedictus, and A. Brand. 1999. Management style and its association with bulk milk somatic cell count and incidence rate of clinical mastitis. J. Dairy Sci. 82:1655-1663.

Barnouin, J., S. Bord, S. Bazin, and M. Chassagne. 2005. Dairy management practices associated with incidence rate of clinical mastitis in low somatic cell score herds in France. J. Dairy Sci. 88:3700-3709.

Bartlett, P. C., G. Y. Miller, S. E. Lance, and L. E. Heider. 1992. Environmental and managerial determinants of somatic cell counts and clinical mastitis incidence in Ohio dairy herds. Prev. Vet. Med. 14:195-207.

Bradley, A. J., K. A. Leach, J. E. Breen, L. E. Green, and M. J. Green. 2007. Survey of the incidence and aetiology of mastitis on dairy farms in England and Wales. Vet. Rec. 160:253-258.

Brown, L. H., E. M. Peterson, and L. M. de la Maza. 1983. Rapid identification of enterococci. J. Clin. Microbiol. 17:369-370.

Daniel, R. C., D. O’Boyle, M. S. Marek, and A. J. Frost. 1982. A survey of clinical mastitis in South-East Queensland dairy herds. Aust. Vet. J. 58:143-147.

Dohoo, I. R., S. W. Martin, A. H. Meek, and W. C. D. Sandals. 1983. Disease, production and culling in Holstein-Friesian cows. I. The data. Prev. Vet. Med. 1:321-334.

Dohoo, I. R., W. Martin, and H. Stryhn. 2003. Veterinary Epidemiologic Research. AVC Inc., University of Prince Edward Island, Charlottetown, Prince Edward Island, Canada.

Erskine, R. J., R. J. Eberhart, L. J. Hutchinson, S. B. Spencer, and M. A. Campbell. 1988. Incidence and types of clinical mastitis in dairy herds with high and low somatic cell counts. J. Am. Vet. Med. Assoc. 192:761-765.

Fox, L. K., and J. M. Gay. 1993. Contagious mastitis. Vet. Clin. North Am. Food Anim. Pract. 9:475-487.

Gröhn, Y. T., R. N. González, D. J. Wilson, J. A. Hertl, G. Bennett, H. Schulte, and Y. H. Schukken. 2005. Effect of pathogen-specific clinical mastitis on herd life in two New York State dairy herds. Prev. Vet. Med. 71:105-125.

Hogan, J. S., R. N. González, R. J. Harmon, S. C. Nickerson, S. P. Oliver, J. W. Pankey, and K. L. Smith. 1999. Laboratory Handbook on Bovine Mastitis. Natl. Mastitis Counc. Inc., Verona, WI.

Jarp, J. 1991. Classification of coagulase-negative staphylococci isolated from bovine clinical and subclinical mastitis. Vet. Microbiol. $27: 151-158$

Jayarao, B. M., S. R. Pillai, A. A. Sawant, D. R. Wolfgang, and N. D. Hegde. 2004. Guidelines for monitoring bulk tank somatic cell and bacterial counts. J. Dairy Sci. 87:3561-3573.

Kivaria, F. M., J. P. Noordhuizen, and H. M. Msami. 2006. Risk factors associated with the incidence rate of clinical mastitis in smallholder dairy cows in the Dar es Salaam region of Tanzania. Vet. J. 78:274-285.

Lam, T. J. G. M., Y. H. Schukken, F. J. Grommers, J. A. Smit, and A. Brand. 1993. Within-herd and between-herd variation in diagnosis of clinical mastitis in cattle. J. Am. Vet. Med. Assoc. 202:938-942.

Lauritsen, J. M., and M. Bruus. 2006. EpiData Entry (version 3.1). Data management and basic statistical analysis system. The EpiData Association, Odense, Denmark.

McDougall, S. 1998. Efficacy of two antibiotic treatments in curing clinical and subclinical mastitis in lactating dairy cows. N. Z. Vet. J. 46:226-232.

McDougall, S. 1999. Prevalence of clinical mastitis in 38 Waikato dairy herds in early lactation. N. Z. Vet. J. 47:143-149.

McLaren, C. J., K. D. Lissemore, T. F. Duffield, K. E. Leslie, D. F. Kelton, and B. Grexton. 2006. The relationship between herd level disease incidence and a return over feed index in Ontario dairy herds. Can. Vet. J. 47:767-773.

Meek, A. H., S. W. Martin, J. B. Stone, I. McMillan, J. B. Britney, and D. G. Grieve. 1986. The relationship among current management systems, production, disease and drug usage on Ontario dairy farms. Can. J. Vet. Res. 50:7-14.

Norman, H. D., R. H. Miller, J. R. Wright, and G. R. Wiggans. 2000. Herd and state means for somatic cell count from dairy herd improvement. J. Dairy Sci. 83:2782-2788.

Nyman, A. K., T. Ekman, U. Emanuelson, A. H. Gustafsson, K. Holtenius, K. P. Waller, and C. H. Sandgren. 2006. Risk factors 
associated with the incidence of veterinary-treated clinical mastitis in Swedish dairy herds with a high milk yield and a low prevalence of subclinical mastitis. Prev. Vet. Med. 78:142-160.

Olde Riekerink, R. G. M., H. W. Barkema, D. F. Kelton, G. P. Keefe, and D. T. Scholl. 2006a. Risk factors for herd-level infection of contagious mastitis pathogens on Canadian dairy farms. In Proc. XIth Symp. Int. Soc. Vet. Epidemiol. Econ., Cairns, Australia.

Olde Riekerink, R. G. M., H. W. Barkema, S. Veenstra, D. E. Poole, R. T. Dingwell, and G. P. Keefe. 2006b. Prevalence of contagious mastitis pathogens in bulk tank milk in Prince Edward Island. Can. Vet. J. 47:567-572.

Østerås, O., S. W. Martin, and V. L. Edge. 1999. Possible risk factors associated with penicillin-resistant strains of Staphylococcus aureus from bovine subclinical mastitis in early lactation. J. Dairy Sci. 82:927-938.

Peeler, E. J., M. J. Green, J. L. Fitzpatrick, K. L. Morgan, and L. E. Green. 2000. Risk factors associated with clinical mastitis in low somatic cell count British dairy herds. J. Dairy Sci. 83:2464-2472.

Reksen, O., L. Sølverod, A. J. Branscum, and O. Østerås. 2006. Relationships between milk culture results and treatment for clinical mastitis or culling in Norwegian dairy cattle. J. Dairy Sci. 89:2928-2937.

Reneau, J. K., and V. S. Packard. 1991. Monitoring mastitis, milk quality and economic losses in dairy fields. Dairy Food Environ. San. 11:4-11.

Roberson, J. R., L. D. Warnick, and G. Moore. 2004. Mild to moderate clinical mastitis: Efficacy of intramammary amoxicillin, frequent milk-out, a combined intramammary amoxicillin, and frequent milk-out treatment versus no treatment. J. Dairy Sci. 87:583592.

Sargeant, J. M., H. M. Scott, K. E. Leslie, M. J. Ireland, and A. Bashiri. 1998. Clinical mastitis in dairy cattle in Ontario: Frequency of occurrence and bacteriological isolates. Can. Vet. J. 39:33-38.

Schepers, J. A., and A. A. Dijkhuizen. 1991. The economics of mastitis and mastitis control in dairy cattle: A critical analysis of estimates published since 1970. Prev. Vet. Med. 10:213-224.
Schukken, Y. H., F. J. Grommers, J. A. Smit, D. van de Geer, and A. Brand. 1989a. Effect of freezing on bacteriologic culturing of mastitis milk samples. J. Dairy Sci. 72:1900-1906.

Schukken, Y. H., F. J. Grommers, D. van de Geer, and A. Brand. 1989b. Incidence of clinical mastitis on farms with low somatic cell counts in bulk milk. Vet. Rec. 125:60-63.

Sears, P. M., B. S. Smith, P. B. English, P. S. Herer, and R. N. González. 1990. Shedding pattern of Staphylococcus aureus from bovine intramammary infections. J. Dairy Sci. 73:2785-2789.

Seegers, H., C. Fourichon, and F. Beaudeau. 2003. Production effects related to mastitis and mastitis economics in dairy cattle herds. Vet. Res. 34:475-491.

Smith, K. L., and J. S. Hogan. 1993. Environmental mastitis. Vet. Clin. North Am. Food Anim. Pract. 9:489-498.

Taponen, S., and S. Pyörälä. 2007. How important are coagulasenegative staphylococci as a cause of mastitis? Pages 81-91 in Proc. NMC 46th Annu. Mtg., San Antonio, TX. Natl. Mastitis Counc. Inc., Verona, WI.

Van Dorp, R. T., S. W. Martin, M. M. Shoukri, J. P. Noordhuizen, and J. C. Dekkers. 1999. An epidemiologic study of disease in 32 registered Holstein dairy herds in British Columbia. Can. J. Vet. Res. 63:185-192.

Wilesmith, J. W., P. G. Francis, and C. D. Wilson. 1986. Incidence of clinical mastitis in a cohort of British dairy herds. Vet. Rec. 118:199-204.

Zadoks, R. N., and M. A. Munoz. 2007. The emergence of Klebsiella as a major mastitis organism. Pages 100-111 in Proc. NMC 46th Annu. Mtg., San Antonio, TX. Natl. Mastitis Counc. Inc., Verona, WI.

Zadoks, R. N., L. L. Tikofsky, and K. J. Boor. 2005. Ribotyping of Streptococcus uberis from a dairy's environment, bovine feces and milk. Vet. Microbiol. 109:257-265.

Zorah, K. T., R. C. Daniel, and A. J. Frost. 1993. Detection of bacterial antigens in milk samples from clinical cases of bovine mastitis in which culture is negative. Vet. Rec. 132:208-210. 